\title{
Dukungan Suami Dengan Pemilihan Pengunaan Kontrasepsi Intra Uterine Device (IUD)
}

\section{Husband Support With Using of Intra Uterine Device (IUD)}

Titik Mariati *

*STIKES Surya Global Yogyakarta

Email : titik_pct@yahoo.com

\begin{abstract}
ABSTRAK
Pada Tahun 2017 peserta Keluarga Berencana (KB) aktif berdasarkan alat kontrasepsi IUD di Kabupaten Bantul yang tertinggi terdapat di Kecamatan Banguntapan yaitu sebanyak 4.883 peserta KB IUD. Tujuan penelitian ini untuk mengetahui dukungan suami dengan pemilihan pengunaan kontrasepsi IUD pada PUS di Dusun Plumbon Desa Banguntapan Kecamatan Banguntapan Bantul Yogyakarta Tahun 2018.Jenis penelitian ini adalah penelitian deskriptif kuantitatif dengan rancangan penelitian case control yaitu suatu penelitian (survei) analitik yang menyangkut bagaimana faktor resiko dipelajari dengan menggunakan pendekatan retrospective. Populasi pada penelitian ini sebanyak 127 dengan sampel sebanyak 56. Dukungan Suami di Dusun Plumbon sebagian besar termasuk dalam kategori tidak mendukung pada kelompok kasus yaitus ebanyak 39 responden (34,8\%) dan kelompok control yang mendukung 31 responden (27,7\%), analisa data menggunakan Chi Square dengan nilai $\mathrm{X}^{2}$ hitung sebesar 6,161 dengan nilai signifikan ( $p$ value) 0,013 >0,05. Tidak Ada hubungan yang signifikan antara dukungan suami dengan pemilihan penggunaan kontrasepsi IUD di Dusun Plumbon Desa Banguntapan Kecamatan Banguntapan, Bantul, Yogayakarta.
\end{abstract}

Kata Kunci :Dukungan Suami, Pemilihan Kontrasepsi IUD.

\begin{abstract}
In the year 2017 the active family planning participants based on IUD contraceptives in Bantul District is highest in District Banguntapan that is as many as 4883 participants Family Planning IUDto know the Dean Husband Support Relationship Selection of IUD Contraception Use in EFA in Plumbon Hamlet Village Banguntapan Village, Banguntapan District, Bantul, Yogyakarta in 2018.The type of this research is quantitative descriptive research with case control research design that is an analytic (survey) research concerning how risk factor is studied by using retrospective approach. The population in this study was 127 with sample of 56.husband support in Plumbon Hamlet mostly included in category not support in case group that is counted 39 respondents $(34,8 \%)$ and control group that support 31 respondents $(27,7 \%)$, analyze data using Chi Square with value $X 2$ count equal to 6,161 with significant value ( $p$ value) 0.013> 0.05.No significant relationship between husband support with IUD contraception use election in Plumbon Village Banguntapan Village Banguntapan Subdistrict, Bantul, Yogayakarta.
\end{abstract}

Keywords : Support Husband, IUD Contraception Selection 


\section{PENDAHULUAN}

Hasil Survei Demografi dan Kesehatan Indonesia (SDKI) 2012, ditemukan bahwa angka kelahiran total TFR (Total Fertility Rate) sebesar 2,6 per wanita hal itu tidak mengalami penurunan dalam kurun 10 tahun terakhir sejak SDKI 20022003.Tingkat prevelensi pemakaian alat kontrasepsi menunjukan tingkat kesertaan KB diantara pasangan usia subur mencapai 61,9\% sebanyak 57,9\% diantaranya mengunakan cara KB moderen, meningkat sebesar 0,5\% dari 57,4\% dalam lima tahun terakhir.pengunaan kontrasepsi didominasi oleh alat kontrasepsi jangka pendek, terutama suntikan yang mencapai 31,9\% tingkat pemakaian metode KB jangka pajang yaitu IUD. Implan metode operasi pria (Vasektomi) dan metode operasi wanita (Tubektomi) 10,6\%.

Alat kontrasepsi adalah alat yang digunakan oleh pasangan suami istri yang ingin mengatur jarak kehamilan cakupan peserta KB baru dan KB aktif pada profil kesehatan 2010, jumlah pasangan usia subur PUS (Pasangan Usia Subur) di indonesia mencapai 44.738.378 orang dengan jumlah peserta KB baru 8.647.024 orang, dan jumlah peserta KB aktif 33.713.115 orang. Persentasi peserta KB aktif menurut metode kontrasepsi di indonesia yaitu IUD peserta KB IUD baru menurut metode kontrasepsi di indonesia sebanyak IUD 5,97\%, (Depkes $\mathrm{RI}, 2010)$.

Faktor yang mempengaruhi perkembangan KB di Indonesia yaitu sosial ekonomi, budaya, pendidikan, agama, dan status wanita (Handayani, 2010). Faktor yang mempengaruhi menurut Sulistiawati (2010) dalam penelitian Kristina (2012) yaitu ada beberapa faktor mempengaruhi pemilihan alat kontrasepsi seperti efektifitas, keamanan, frekuensi pemakaian, efek samping serta kemauan dan kemampuan untuk melakukan kontrasepsi secara teratur dan benar pertimbngan kontrasepsi juga di dasarkan atas biaya serta peran dari agama dan kultur budaya mengenai alat kontasepsi tersebut, dan faktor lainya adalah frekuensi melakukan hubungan seksual.

Namun, fakta yang patut mendapat perhatian lebih dalam beberapa tahun terakhir adalah perubahan pola pemakaian kontrasepsi dimana metode kontrasepsi yang diminati akseptor antara lain suntik pada pilihan pertama, pil pilihan kedua, 
Titik Mariati : Dukungan Suami Dengan Pemilihan ....

implan ketiga, dan AKDR (Alat Kontrasepsi Dalam Rahim) pilihan keempat. Pola pemakaian menujukkan kecederungan peningkatan metode kontrasepsi suntik dan pil, sebaliknya pamakaian motede kontrasepsi AKDR cenderung menurun dari waktu ke waktu. Hal ini terlihat dari sedikitnya pertambahan jumlah akseptor AKDR baru dari tahun ke tahun menurunnya jumlah pengguna ulang AKDR, serta banyaknya jumlah akseptor AKDR yang mengganti metode dari AKDR ke metode lain (BKKBN,2014).

Berbagai upaya pemerintah yang dapat dilakukan untuk meningkatkan pemakaian alat kontrasepsi jangka panjang seperti AKDR (Alat Kontrasepsi Dalam Rahim) agar dapat menurunkan angka kelahiran di indonesia adalah memotivasi PUS (Pasangan Usia Subur) dan WUS (Wanita Usia Subur) berusia tua (lebih dari 35 tahun) yang telah memiliki 2 orang anak yang masih hidup dan relatif muda. Penyedian alat kontrasepsi untuk semua klinik KB pemerintah serta dukungan sarana KIA KB yang lenkap dan promosi tentang MKJP (Metode KB Jangka Panjang) seperti AKDR. Peningkatan kompetisi provider dalam pelayanan AKDR serta memprioritaskan kualitas pelayanan AKDR dengan lebih memperhatikan rekruitmen calon klain dan pencitraan tempat pelayanan. Dengan demikian klain bisa termotivasi untuk meningkatkan persitisipasinya dalam menggunakan AKDR karena adanya dukungan dari semua aspek (BKBN, 2014).

Berdasarkan informasi dari PLKB Desa Banguntapan bahwa jumlah penduduk paling besar terdapat di Desa Banguntapan sehingga mengakibatkan pasangan usia subur memiliki angka yang cukup besar. Pemilihan kontrasepsi IUD tidak lepas dari adanya dukugan suami karena suami adalah kepala keluarga yang menetukan setiap keputusan. Selain itu dari hasil saya survey menunjukan bahwa data KB IUD didusun Pelumbon sangat tinggi dibandingkan dusun lain.

\section{METODE}

Jenis penelitian yang digunakan dalam penelitian ini adalah penelitian deskriptif kuantitatif. Menggunakan pendekatan case control bagaimana faktor resiko dipelajari dengan menggunakan pendekatan retrospective (Notoatmodjo, 2014). Populasi dalam penelitian ini berjumah 127 orang yang menggunakan 
kontrasepsi IUD. Pengambilan Sampel dalam penelitian ini menggunakan purposive sampling. Bersarnya jumlah sampel ditentukan dengan perhitungan mengunakan rumus slovin dengan total jumlah keseluruhan 56 sampel. Sumber primer adalah dengan menggunakan kuesioner, dalam penelitian ini data sekunder didapatkan dari Kantor DPPKBPMD Bantul, PLKB Kecamatan Banguntapan,dan Kader Dusun Plumbon.Peneliti menggunakan analisis univariat. Untuk dukungan dan minat responden, penulis menggunakan analisa secara univariat dengan formula (Arikunto, 2006). Analisis bevariate yang dilakukan terhadap dua variabel yang diduga berhubungan atau berkorelasi (Notoatmodjo, 2010).

Analisis bivariate adalah analisis yang menunjukkan hubungan antara satu variabel independent dan satu variabel dependent (Lapau, 2013). Jika skala pengukuran kategori (ordinal dan nominal maka diuji dengan uji non parametik. Uji bivariat pada penelitian ini menggunakan uji statistik Chi Square (Riyanto, 2011).Teknik ini digunakan untuk mengadakan pendekatan dari beberapa faktor atau mengevaluasi frekuensi yang diharapkan dari sampel apakah terdapat perbedaan yang signifikan atau tidak. Metode ini digunakan untuk skala data nominal dan ordinal (Riyanto, 2011).

\section{HASIL}

Karakteristrik Responden Berdasarkan Umur Pengelompokan responden berdasarkan kategori umur digambarkan sebagai berikut :

Tabel 1. Distribusi Frekuensi Responden Menurut Umur Di Dusun Plumbon Desa Banguntapan Kecamatan Banguntapan Bantul Yogyakarta Tahun 2018

\begin{tabular}{ccrr}
\hline No & Variabel umur & \multicolumn{2}{c}{ Responden } \\
\cline { 3 - 4 } & & Jumlah & \multicolumn{2}{c}{ Persentase (\%) } \\
\hline 1 & $18-27$ & 3 & 2,7 \\
2 & $28-37$ & 29 & 25,9 \\
3 & $38-47$ & 51 & 45,5 \\
4 & $48-57$ & 28 & 25,0 \\
5 & $58-67$ & 1 & 0,9 \\
\hline Total & & $\mathbf{1 1 2}$ & $\mathbf{1 0 0}$ \\
\hline
\end{tabular}

BerdasarkanTabel 1 dapat diketahui bahwa jumlah sampel terbanyak terdapat pada umur 38-47 yaitu sebanyak 51 responden dengan prosentase 45,5\%. Pengelompokan responden berdasarkan kategori tingkat pendidikan digambarkan sebagai berikut : 
Titik Mariati : Dukungan Suami Dengan Pemilihan ....

Tabel 2. Distribusi Frekuensi Responden Menurut Tingkat Pendidikan Di Dusun Plumbon Desa Banguntapan Kecamatan Banguntapan Bantul Yogyakarta Tahun 2018

\begin{tabular}{llrr}
\hline No & Variabel Pendidikan & \multicolumn{2}{c}{ Responden } \\
\cline { 3 - 4 } & & Jumlah & \multicolumn{2}{c}{ Persentase (\%) } \\
\hline 1 & D3 & 9 & 8,0 \\
2 & S1 & 20 & 17,9 \\
3 & S2 & 4 & 3,6 \\
4 & SD & 12 & 10,7 \\
5 & SMA & 31 & 27,7 \\
6 & SMK & 17 & 15,2 \\
7 & SMP & 19 & 17,0 \\
\hline \multicolumn{2}{l}{ Total } & 112 & 100 \\
\hline
\end{tabular}

Berdasarkan Tabel 2 dapat diketahui bahwa jumlah sampel terbesar terdapat pada tingkat pendidikan SMA yaitu sebanyak 31 responden sebesar 27,7\%. Pengelompokan responden berdasarkan kategori dukungan suami digambarkan sebagai berikut :

Tabel 3. Distribusi Frekuensi Responden Menurut Dukungan Suami Di Dusun Plumbon Desa Banguntapan Kecamatan Banguntapan Bantul Yogyakarta Tahun 2018

\begin{tabular}{clrr}
\hline \multirow{2}{*}{ No } & Variabel dukungan suami & \multicolumn{2}{c}{ Responden } \\
\cline { 3 - 4 } & & Jumlah & Persentase (\%) \\
\hline 1 & Mendukung & 48 & 42,9 \\
2 & Tidak mendukung & 64 & 57,1 \\
\hline Total & & $\mathbf{1 1 2}$ & $\mathbf{1 0 0}$ \\
\hline
\end{tabular}

Berdasarkan Tabel 3 pada variabel dukungan suami dapat diketahui bahwa jumlah terbanyak pada dukungan suami berjumlah 48 responden dengan prosentase 42,9\%. Pengelompokan responden berdasarkan kategori pemilihan kontrasepsi digambarkan sebagai berikut :

Tabel 4. Distribusi Frekuensi Responden Menurut Pemilihan Kontrasepsi Di Dusun Plumbon Desa Banguntapan Kecamatan Banguntapan Bantul Yogyakarta Tahun 2018

\begin{tabular}{clrr}
\hline \multirow{2}{*}{ No } & \multirow{2}{*}{ Variabel Pemilihan Kontrasepsi } & \multicolumn{2}{c}{ Responden } \\
\cline { 3 - 4 } & Memilih & Jumlah & Prosentase (\%) \\
\hline 1 & Tidak Memilih & 56 & 50.0 \\
\hline Total & & 56 & 50.0 \\
\hline
\end{tabular}


Berdasarkan Tabel 4 pada variabel pemilihan kontrasepsi dapat diketahui bahwa masing-masing responden memilki jumlah yang sama pada responden yang mengunakn IUD atau tidak mengunakan IUD. Uji Chi Square yang digunakan dengan nilai signifikasi $10 \%(\mathrm{a}=0,1)$ dengan menggunakan SPSS versi 17 dapat digambarkan sebagai berikut :

\section{Tabel 5. Hasil Crosstabulation}

\begin{tabular}{|c|c|c|c|c|c|c|c|}
\hline \multirow{3}{*}{ DukunganSuami } & \multicolumn{5}{|c|}{ Responden } & \multirow{2}{*}{\multicolumn{2}{|c|}{ Jumlah }} \\
\hline & \multirow{2}{*}{\multicolumn{2}{|c|}{$\begin{array}{l}\text { Kasus } \\
\mathrm{n}\end{array}$}} & \multicolumn{3}{|c|}{ Kontrol } & & \\
\hline & & & $\%$ & $\mathrm{n}$ & $\%$ & $\mathrm{n}$ & $\%$ \\
\hline Tidakmendukung & 39 & 34,8 & 25 & 22,3 & & 64 & 57,1 \\
\hline Mendukung & 17 & 15,2 & 31 & 27,7 & & 48 & 42,9 \\
\hline Total & 56 & 50 & 56 & 50 & & 112 & 100 \\
\hline
\end{tabular}

Berdasarkan tabel 5 hasil analisis Hubungan Dukungan Suami Dengan Pemilihan Pengunaan Kontrasepsi IUD Pada PUS Di Dusun Plumbon dapat dilihat pada kelompok kasus yaitu sebanyak 17 responden atau (15,2\%) dengan kategori mendukung dan untuk kategori tidak mendukung sebanyak 39 responden atau (34,8\%). Sedangkan untuk kelompok control dukungan suami yang tidak mendukung sebanyak 25 responden atau (22,3\%) dan untuk dukungan suami yang mendukung sebanyak 31 responden atau (27,7\%).

Tabel 6. Hasil Uji Korelasi Menggunakan Chi Square Correlation

\section{Chi-Square Tests}

\begin{tabular}{|c|c|c|c|c|c|}
\hline & Value & df & $\begin{array}{l}\text { Asymp. Sig. } \\
\text { (2-sided) }\end{array}$ & \begin{tabular}{|lr} 
Exact Sig. \\
(2-sided)
\end{tabular} & $\begin{array}{|lll|}\begin{array}{l}\text { Exact } \\
\text { sided) }\end{array} & \text { Sig. } & \text { (1- } \\
\end{array}$ \\
\hline Pearson Chi-Square & $7.146^{\mathrm{a}}$ & 1 & .008 & & \\
\hline Continuity Correction & 6.161 & 1 & .013 & & \\
\hline Likelihood Ratio & 7.231 & 1 & .007 & & \\
\hline Fisher's Exact Test & & & & .013 & .006 \\
\hline $\begin{array}{l}\text { Linear-by-Linear } \\
\text { Association }\end{array}$ & 7.082 & 1 & .008 & & \\
\hline McNemar Test & & & & $.280^{c}$ & \\
\hline $\mathrm{N}$ of Valid Cases & 112 & & & & \\
\hline
\end{tabular}

Berdasarkan Tabel 6 dapat dilihat bahwa 112 responden terdiri dari 56 dengan kontrasepsi IUD dan 56 kontrasepsi Non IUD. Variabel Dukungan suamididapatkan hasil nilai df(Person Chi Square) sebesar 1 dengan taraf 
signifikan 0,007 maka nilai Chi Square tabel 2,706. Adapun nilai Chi Square hitung sebesar 7,231 maka Chi Square hitung >Chi Square tabel, sedangkan nilai Symp. Sig<0,1 yaitu 0,007. Berdasarkan hasil tersebut menunjukkan bahwa ada hubungan yang signifikan antara dukungan suami dengan pemilihan IUD. Artinya dukungan suami mempengaruhi pemilihan kontrasepsi IUD di Dusun Plumbon Desa Banguntapan Kecamatan Banguntapan Bantul Yogyakarta.

\section{PEMBAHASAN}

Dukungan suami sangat penting bagi istri terutama dalam merencanakan kehidupan rumah tangga seperti halnya dalam menentukan metode KB yang akan dipilih. Pemilihan kontrasepsi IUD tidak lepas dari adanya dukungan suami karena suami adalah kepala keluarga yang menetukan setiap keputusan. Suami adalah orang pertama dan utama dalam memberi dorongan kepada istri sebelum pihak lain turut memberi dorongan, dukungan dan perhatian seorang suami terhadap istri yang sedang hamil yang akan membawa dampak bagi sikap bayi (Dagun, 2002). Peran pasangan dalam kehamilan dapat sebagai orang yang memberi asuhan, sebagai orang yang menanggapi terhadap perasaan rentan wanita hamil, baik aspek biologis maupun dalam hubungannya dengan ibunya sendiri (Bobak, Lowdermilk \& Jensen, 2004).

Hasil analisis data menurut karakteristik responden berdasarkan umur didapatkan hasil mayoritas akseptor kontrasepsi di Dusun Plumbon adalah berumur 38-47 tahun atau sebanyak 51 responden dengan persentase (45,5\%). Menurut (Nursalam, 2008) umur merupakan masa perjalanan hidup seseorang, mulai dari lahir sampai batas pengumpulan data, tingkat kematangan dan kekuatan seseorang akan lebih dewasa dipercaya dari orang yang belum tinggi tingkat kedewasaannya. Hal ini adalah bagian dari pengalaman dan kematangan jiwa. Umur seseorang dapat mempengaruhi kecocokan dan aksesbilitas metodemetode kontrasepsi tertentu.

Menurut Komang 2014 mengatakan bahwa suami merupakan pemimpin dan pelindung istri, maka kewajiban suami terhadap istrinya adalah mendidik, mengarahkan serta mengartikan istrinya kepada kebenaran, kemudiaan memberinya nafkah lahir batin, mempergauli serta menyantuni dengan baik. 
Maka untuk hal mendidik istri dalam pengambilan keputusan dan juga berkomunikasi untuk mendiskusikan kebijakan dalam merencanakan keluarga berencana. Sering terjadi dengan tidak adanya diskusi yang baik atau komunikasi yang baik sehingga dapat menjadi hambatan terhadap kelangsungan pemakaian alat kontrasepsi.

Hasil analisis data karakteristik responden berdasarkan tingkat pendidikan diketahui responden terbanyak adalah responden dengan tingkat pendidikan SMA yaitu sebanyak 31 responden dengan persentase (27,7\%). Tingkat pendidikan yang baik mempengaruhi suami dalam mendukung istri untuk menggunakan kontrasepsi. Sehingga suami dapat menerima dan memahami informasi penggunaan alat kontrasepsi dan dapat membantu istri untuk pengambilan keputusan terhadap kontrasepsi yang dipilih (Novita, 2011).

Penelitian ini responden dengan pendidikan SMA (27,7\%) lebih banyak dibandingkan dengan yang lainnya karena responden di Dusun plumbon sebagian besar tidak melanjutkan kejenjang selanjutnya namun pendidikan yang sudah tercapai sudah yang paling tinggi menurut pendapat responden. Pendidikan terakhir SMA responden bisa menerima semua informasi yang disampaikan. Hubungan pendidikan dengan pola pikir dan persepsi serta prilaku masyarakat sangat signifikan, bahwa semakin tinggi tingkat pendidikan seseorang maka semakin rasional dalam pengambilan berbagai keputusan.

Menurut (Handayani, 2012) tingkat pendidikan juga mempengaruh terhadap keinginan individu dan pasangan untuk menentukan jumlah anak. Berbagai penelitian telah membuktikan bahwa tingkat pendidikan mempengaruh terhadap peningkatan penggunaan alat kontrasepsi. Penelitian di Kenya menunjukan bahwa responden yang berpendidikan tinggi secara signifikan berpeluang lebih tinggi mendukung istri untuk mengunakan alat kontrasepsi IUD dan Implan di bandingkan dengan responden yang berpendidikan rendah,sedangkan responden yang tidak sekolah mempunyai peluang yang sangat kecil untuk dapat menerima informasi yang diberikan.

Pemilihan kontrasepsi IUD di Dusun Plumbon hasil penelitian menunjukan responden yang memilih kontrasepsi IUD yaitu sebanyak 56 
responden (50.0\%) diketahui masing-masing responden memiliki jumlah yang sama pada responden yang tidak mengunakan IUD. Pemilihan kontrasepsi merupakan pengambilan keputusan untuk penggunaan alat kontrasepsi (Hartanto, 2010). Alat kontrasepsi yang digunakan untuk mencegah terjadinya kehamilan.

Berdasarkan hasil analisa dapat diketahui bahwa jumlah responden di dusun plumbon desa banguntapan kecamatan banguntapan memiliki Dukungan suami di Dusun Plumbon dapat dilihat pada kelompok kasus yaitu sebanyak 17 responden atau (15,2\%) dengan kategori mendukung dan untuk kategori tidak mendukung sebanyak 39 responden atau (34,8\%). Sedangkan untuk kelompok kontrol dukungan suami yang tidak mendukung sebanyak 25 responden atau (22,3\%) dan untuk dukungan suami yang mendukung sebanyak 31 responden atau (27,7\%).

Hasil analisis dengan uji Chi Square diketahui bahwa nilai Chi Square dapat dilihat bahwa dari 112 responden terdiri dari 56 dengan kontrasepsi IUD dan 56 kontrasepsi Non IUD. Variabel Dukungan suami didapatkan hasil nilai df (Person Chi Square) sebesar 1 dengan taraf signifikan 0,007 maka nilai Chi Square tabel 2,706. Adapun nilai Chi Square hitung sebesar 7,231 maka Chi Square hitung $>$ Chi Square tabel, sedangkan nilai $\alpha$ Symp. Sig $<0,1$ yaitu 0,007. Berdasarkan hasil tersebut menunjukkan bahwa ada hubungan yang signifikan antara dukungan suami dengan pemilihan IUD. Artinya dukungan suami mempengaruhi pemilihan kontrasepsi IUD di dusun plumbon desa banguntapan kecamatan banguntapan bantul Yogyakarta tahun 2018.

Hasil penelitian ini sejalan dengan hasil penelitian yang dilakukan sebelumnya oleh (Supiani, 2015) bahwa terdapat hubungan signifikan antara dukungan suami dengan pemilihan IUD di wilayah kerja Puskesmas Gamping II Sleman Yogyakarta. Hasil analisa menurut peneliti dukungan suami merupakan salah satu faktor yang mempengaruhi pemilihan jenis kontrasepsi yang digunakan PUS.

Hasil penelitian ini juga sesuai dengan teori (WHO,2007) yang menyatakan bahwa hubungan seorang wanita dengan pasangannya juga dapat menjadi faktor dalam menentukan pilihan untuk menggunakan kontrasepsi 
tertentu. Karena pada banyak masyarakat, pasangan tidak saling berkomunikasi mengenai keluarga berencana, pihak wanitalah yang sering kali harus memperoleh dan menggunakan alat kontrasepsi bila ingin mengontrol kesuburannya. Pada sebuah studi di India dan Turki, lebih dari separuh wanita yang diwawancarai mengatakan bahwa penggunaan kontrasepsi mereka dibuat oleh atau dengan suami. Studi yang sama mendapatkan bahwa persetujuan teman atau sanak saudara dalam penggunaan kontrasepsi merupakan hal penting bagi 91\% wanita di Turki, 68\% di Filipina, 67\% di India, dan 54\% di Republik Korea (Hartanto, 2006).

Hasil penelitian ini sejalan dengan penelitian yang telah dilakukan oleh (Pertiwi,2013) dengan judul hubungan antara usia, paritas, dan dukungan suami dengan pemilihan kontrasepsi IUD yang menunjukkan bahwa dukungan suami yang tinggi akan mempengaruhi sikap dalam memilih kontrasepsi yang akan digunakannya.Oleh karena itu tindakan yang dapat dilakukan untuk meningkatkan pemilihan kontrasepsi IUD adalah mengupayakan peningkatan dukungan suami dengan pemberian segala informasi terkait pemilihan metode KB IUD dari kelebihan serta kekurangannya. Dapat dilakukan dengan penyuluhan rutin kepada masyarakat terutama PUS dan akseptor KB.

\section{SIMPULAN}

Alat kontrasepsi adalah alat yang digunakan oleh pasangan suami istri yang ingin menunda/mengaturjarak kehamilan cakupan peserta KB barudan KB aktif pada profil kesehatan 2010, jumlah pasangan usia subur PUS (Pasangan Usia Subur) di Indonesia mencapai 44.738.378 orang dengan jumlah peserta KB baru 8.647.024 orang, dan jumlah peserta KB aktif 33.713.115 orang. Persentasi peserta $\mathrm{KB}$ aktif menurut metode kontrasepsi di Indonesiayaitu IUD peserta KB IUD baru menurut metode kontrasepsi di Indonesia sebanyak IUD 5,97\%, (Depkes RI, 2010).

Pemilihan kontrasepsi IUD tidak lepas dari adanya dukugan suami karena suami adalah kepala keluarga yang menetukan setiap keputusan. Selain itu dari hasil survey menunjukan bahwa data KB IUD di Dusun Plumbon sangat tinggi 
Titik Mariati : Dukungan Suami Dengan Pemilihan ....

dibandingkan Dusun lain. Nilai Chi Square dapat dilihat bahwa dari 112 responden terdiri dari 56 dengan kontrasepsi IUD dan 56 kontrasepsi Non IUD.

Variable Dukungansuami di dapatkan hasil nilai df (Person Chi Square) sebesar 1 dengan taraf signifikan 0,007 maka nilai Chi Square tabel 2,706. Adapun nilai Chi Square hitung sebesar 7,231 maka Chi Square hitung> Chi Square tabel, sedangkan nilai $\alpha$ Symp. Sig $<0,1$ yaitu 0,007. Berdasarkan hasil tersebut menunjukkan bahwa ada hubungan yang signifikan antara dukungan suami dengan pemilihan IUD. Artinya dukungan suami mempengaruhi pemilihan kontrasepsi IUD di Dusun Plumbon Desa Banguntapan Kecamatan Banguntapan Bantul Yogyakarta.

\section{UCAPAN TERIMA KASIH}

Peneliti mengucapkan terimakasih kepada STIKES Surya Global Yogyakarta.

\section{DAFTAR PUSTAKA}

Agus Riyanto, 2011. Aplikasi Metodologi Penelitian Kesehatan.Nuha. Medika Yogyakarta.

Arief, Nurhaeni. 2008. Panduan Lengkap Kehamilan Dan Kelahiran Sehat. Yogyakarta : AR Group

Arikunto, Suharsimi, 2006, ProsedurPenelitian, Rineka Cipta, Jakarta.

Badan Pusat Statistik \& Macro Internasional. 2008.

BKKBN. Tersedia dalam:http://www.bkkbn.go.id> [Diakses pada tanggal 25 Oktober 2014]

Bobak, Lowdermilk, Jensen, 2004, Buku Ajar Keperawatan Maternitas / Maternity nursing (Edisi 4), Alih Bahasa Maria A. Wijayati, peter I. Anugerah, Jakarta : EGC.

Dagun, M. S. (2002). Psikologi Keluarga. Jakarta :Rineka Cipta.

Departemen Kesehatan RI, 2010. Profil Kesehatan 2010.

Handayani, S. (2012). Keluarga Berencana dan Kontrasepsi. Yogyakarta: Pustaka Rihana

Handayani, Sri, S.Si.T, M.Kes., 2010. Buku Ajar Pelayanan keluarga Berencana. Pustaka Rihama, Sewon, Bantul, Yogyakarta

Hartanto. H. 2004. Keluarga berencana dan Kontrasepsi. Jakarta: Pustaka Sinar Harapan.

Irianto, 2014. Pelayanan keluarga berencana.

Irianto, Koes. 2014. Pelayanan Keluarga Berencana dua anak cukup. Bandung: Alfabeta. 
Khorrunnisa, L. 2014. Hubungan Dukungan Suami Dengan Pemilihan Kontrasepsi IUD Pada Akseptor Kontrasepsi IUD Di Puskesmas TegalRejo.

Komang, A. (2014). Hubungan Persepsi Ibu tentang Dukungan Suami Terhadap Tingkat Keberhasilan IMD di Rumah Sakit Yogyakarta. Universitas Gadjah Mada.

Kurniati, A. 2013. Hubungan Dukungan Suami Dengan Pemilihan Metode Kontrasepsi Iud Di Bidan Praktik Mandiri Kecamatan Gunungpati Kota Semarang.

Marmi. 2016. Buku Ajar Pelayanan KB. Yogyakarta : Pustaka Pelajar

Musbikin, imam. 2008. Panduan Bagi Ibu Hamil dan Melahirkan. Yogyakarta : Mitra Pustaka

Notoadmodjo, S. 2010. Metodologi Penelitian Kesehatan. Jakarta: Rineka Cipta

Notoadmodjo, S. 2010.Kriteria Inklusi dan Ekslusi. Jakarta: Rineka Cipta

Notoadmodjo, S. 2014. Ilmu Prilaku Kesehatan. Jakarta: Rineka Cipta

Nursalam, 2008. Konsep dan Penerapan Metodologi Penelitian Ilmu Keperawatan :Jakarta: Salemba Medika

Riwidikdo, H. 2012. Statistic Kesehatan. Yogyakarta: Nuha Madika.

Sabatini, Kristina. 2012. Hubungan Antara Pengetahuan Alat Kontrasepsi Modern Dengan Kehamilan Tidak Diinginkan Pada Wanita Hamil Dan Pasangan Usia Subur di Indonesia(analisis data SDKI). UI, Jakarta.

Supiani, 2015. Hubungan Dukungan Suami Terhadap Penggunaan Alat Kontrasespsi Dalam Rahim Di Wilayah Kerja Puskesmas Gamping II Sleman Yogyakarta.

Survei Demografi \& Kesehatan Indonesia (SDKI). 2012. Tingkat Kesertaan KB.

Wahyuno. F. 2017, Profil Desa Banguntapan. Yogyakata. 